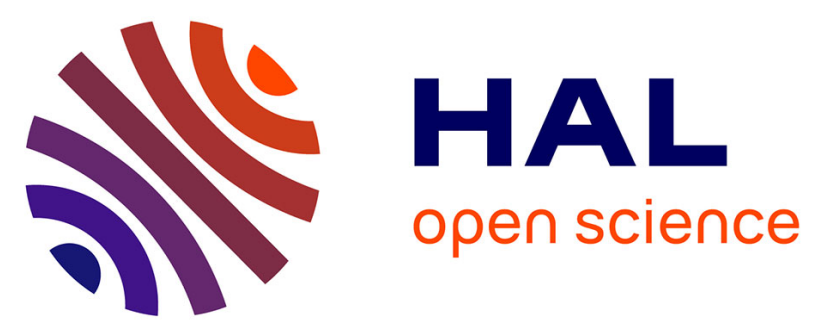

\title{
Hydrogen production during the irradiation of gaseous organic compounds: advantage of an extracted beam
}

C. Pichon, A. Chevarier, J.-C. Duclot, A. Gardon, J.-C. Marchand, N. Millard-Pinard, C. Peaucelle, M. Pijolat, F. Valdivieso

\section{- To cite this version:}

C. Pichon, A. Chevarier, J.-C. Duclot, A. Gardon, J.-C. Marchand, et al.. Hydrogen production during the irradiation of gaseous organic compounds: advantage of an extracted beam. Eighth European Conference on Accelerators in Applied Research and Technology (ECAART-8), Sep 2004, Paris, France. pp.589-594, 10.1016/j.nimb.2005.06.229 . in2p3-00024645

HAL Id: in2p3-00024645

https://hal.in2p3.fr/in2p3-00024645

Submitted on 22 Sep 2005

HAL is a multi-disciplinary open access archive for the deposit and dissemination of scientific research documents, whether they are published or not. The documents may come from teaching and research institutions in France or abroad, or from public or private research centers.
L'archive ouverte pluridisciplinaire HAL, est destinée au dépôt et à la diffusion de documents scientifiques de niveau recherche, publiés ou non, émanant des établissements d'enseignement et de recherche français ou étrangers, des laboratoires publics ou privés. 
Abstract ID: P2-66

Hydrogen production during the irradiation of gaseous organic compounds: advantage of an extracted beam

C. Pichon ${ }^{\mathrm{a}, \mathrm{b}}$, A. Chevarier ${ }^{\mathrm{a}}$, J.C. Duclot ${ }^{\mathrm{a}}$, A. Gardon ${ }^{\mathrm{a}}$, J.C. Marchand ${ }^{\mathrm{b}}$, N.Millard-Pinard ${ }^{\mathrm{a}}$, C. Peaucelle $^{\mathrm{a}}$, M.Pijolat ${ }^{\mathrm{b}}$, F. Valdivieso ${ }^{\mathrm{b}}$.

${ }^{\text {a }}$ Institut de Physique Nucléaire de Lyon, 4 rue Enrico Fermi, 69622 Villeurbanne Cedex, France

${ }^{\mathrm{b}}$ Ecole Nationale Supérieure des Mines de Saint Etienne, 158 cours Fauriel, 42033 Saint Etienne Cedex, France.

\begin{abstract}
-
This paper presents a fundamental study of the radiolysis of gaseous organic molecules induced by proton beam. For that purpose, a specific extracted beam line associated with a gas irradiation cell was set up on the 4 MV facility of the Institut de Physique Nucléaire of Lyon. The first experiments have been performed with gaseous alkanes and alkenes. The gaseous species formed during irradiation are analysed by an on-line gas chromatography instrument equipped with two detectors. In order to test our experimental facility, we have studied the influence of irradiation parameters (duration, beam intensity, pressure) on the production of hydrogen. In the case of propane, the radiolytic yield value of hydrogen $\mathrm{G}\left(\mathrm{H}_{2}\right)$ is equal to 3.7 for total doses in the range of 0.4 to 2.3 MGy at atmospheric pressure.

PACS: 61.80.Lj, 61.82.Pv

Keywords: extracted beam, irradiation, hydrogen production, propane radiolysis.

Corresponding author:

C. Pichon

Institut de Physique Nucléaire de Lyon

4 rue Enrico Fermi

69622 Villeurbanne Cedex

France

e-mail: pichon@ipnl.in2p3.fr

Phone: +33472431464

Fax: +33472448004
\end{abstract}




\section{Introduction}

Numerous laboratories have studied the production of hydrogen during the irradiation of gaseous organic compounds principally with $\gamma$ radiations [1-5]. Very few results concerning irradiation with protons or alpha particles [6] were published. This can be explained by the instability of some organics materials under vacuum.

In order to analyse samples in air and to irradiate organic or inorganic compounds, at liquid or gaseous state, an extracted beam line was developed on the 4 MV Van de Graaff accelerator of IPN Lyon.

This paper will first present some criteria that have guided the design of this line, and then detailed features of the line and of the irradiation cell.

Identification and quantitative analysis of compounds formed during radiolysis of gaseous hydrocarbons were performed by gas chromatography connected to the irradiation cell.

Finally, we will present the influence of dose rate, dose, pressure and gas mixture on the radiolytic yields of products formed during the radiolysis of propane, butane and butene with proton particles.

\section{Experimental}

\subsection{Characteristics of the extracted beam line}

The schematic representation of the extracted beam line is given in figure 1. The beam is extracted to the air through a 10 micrometers thick Havar window on a $60 \mathrm{~mm}^{2}$ surface. The choice of havar is justified by its excellent mechanical properties and its behaviour under irradiation. The 10 micrometers thickness represents a compromise between on one hand energy and angular dispersions resulting from the straggling during the crossing of the sheet and on the other hand the risk of micro crack formation leading to a leakage rate incompatible with the quantitative measurement of hydrogen production under irradiation. 
In order to protect the accelerator from the Havar window breakdown, an ultra fast closing valve VAT model 75 (closing time $<10 \mathrm{~ms}$ ) is fixed at the exit of the analysing magnet vacuum chamber. That ultra fast closing valve is controlled by fast electronics. The sensor is located after the focusing quadripoles and in the immediate vicinity of the thin window. The distance of 6 meters between the sensor and the ultra fast closing valve is necessary. Moreover, in order to limit vacuum degradation resulting from a window rupture, a fast closing valve (closing time of 1/10 second), is placed immediately upstream of the sensor. Its control is also provided by the fast sensor.

Under normal operation conditions, the diameter of the beam spot is one millimeter. In order to irradiate solids or liquids with homogeneous flux on a well-delimited surface, a sweeping electrostatic device $(\Delta \mathrm{x}= \pm 8 \mathrm{~mm}, \Delta \mathrm{y}= \pm 8 \mathrm{~mm})$ of the beam, not used for gases, was set up.

The cell is made of stainless steel (304L). Owing to the fact that a variation of gas pressure changes the proton ranges by the same factor axially and radially, simulations using the SRIM [7] code allowed the optimisation of the cell dimensions. For protons of $3.0 \mathrm{MeV}$ incident kinetic energy, the energy at the exit window is $2.45 \mathrm{MeV}$. The ion distributions (figure 2) for two different pressures (500 and 1000 mbar of propane) show that the minimum diameter of the cell must be larger than 12 $\mathrm{mm}$ and the length equal to $105 \mathrm{~mm}$, so that most particles are stopped within the gas.

The cell is equipped with three tappings allowing pre emptying of the cell, gas loading and continuous pressure measurement.

\subsection{Irradiation conditions}

In the experiments described below, the dependence of the radiolytic yield values $\mathrm{G}$ on irradiation parameters is studied. In order to modify the dose rate, the beam current intensity was varied between 5 and $15 \mathrm{nA}$. The dose is calculated assuming that protons are stopped in the gas and that the whole cell volume is concerned by irradiation. The cell is emptied with a primary pumping before hydrocarbon introduction. A piezoelectric gauge controls the pressure inside the cell. All G- 
values are expressed as produced molecules per 100 electron volts. G-values are calculated from the mole number (determined by gas chromatography) and from the proton deposited energy. Propane, butane, and butene were Messer research grade (purity $=99.95 \%$ ).

\subsection{Gas analysis}

The radiolysis of gaseous hydrocarbons predominantly results in the formation of hydrogen and various saturated and unsaturated organic compounds. The irradiated gas was analysed by gas chromatography. A Chrompack model CP9001 gas chromatograph includes with two analysis channels, equipped with two injection pneumatic valves.

Gaseous hydrocarbons were detected by a flame ionisation detector on channel A, which has a capillary column $\left(1=100 \mathrm{~m}, \mathrm{~V}_{\mathrm{inj}}=250 \mu \mathrm{L}\right)$. Quantification of hydrogen formed during irradiation is performed on channel B equipped with a $5 \AA$ column molecular sieve $\left(1=65 \mathrm{~cm}, \mathrm{~V}_{\mathrm{inj}}=500 \mu \mathrm{L}\right)$ and a thermal conductibility detector. This column also permits to detect the presence of air, which is an indication of possible leaks in the irradiation cell.

The carrier gas was argon (Alphagaz 2 with specifications: $\mathrm{H}_{2} \mathrm{O}<0.5$ ppm et $\mathrm{O}_{2}, \mathrm{CO}, \mathrm{CO}_{2}, \mathrm{C}_{\mathrm{n}} \mathrm{H}_{\mathrm{m}}$, $\mathrm{N}_{2}, \mathrm{H}_{2}<0.1 \mathrm{ppm}$ ) with a flow of $1 \mathrm{~mL}$ per minute on channel A and $8 \mathrm{~mL}$ per minute on channel $\mathrm{B}$. The produced gas was identified by comparison of the retention time with those of standard samples. The experimental error is assumed to be about $5 \%$ for hydrogen and less than $10 \%$ for hydrocarbons.

\section{Results}

\subsection{Dose rate effect on the hydrogen production}

Preliminary results shown that $\mathrm{G}\left(\mathrm{H}_{2}\right)$ does not depend on the dose rate below $75 \mathrm{MGy} / \mathrm{h}: \mathrm{G}\left(\mathrm{H}_{2}\right)$ is equal to 3.4 molecules per 100 electron volts. 


\subsection{Dose effect on hydrogen and hydrocarbon production}

The total absorbed dose was varied between 0.4 and 2.3 MGy at a constant total pressure of 1 bar and a constant total dose rate of about $50 \mathrm{MGy} / \mathrm{h}$. Saturated and unsaturated hydrocarbons were irradiated: propane, butane, butene and a mixture 1:1 of propane and butene.

Figure 3 shows the dependence of the G-values of hydrogen, methane, ethane, ethylene and nbutane formed during propane radiolysis with the total absorbed dose. The identification of other formed hydrocarbons is in progress.

As we can see in figure 3, the G-values of hydrogen are almost independent on the dose except in the range above 0.8 MGy, where the G-value decrease with increasing dose. In the dose range from 0.4 to $0.8 \mathrm{MGy}, \mathrm{G}\left(\mathrm{H}_{2}\right)$ is equal to 3.7. Above $0.8 \mathrm{MGy}$, the observed decrease of $\mathrm{G}\left(\mathrm{H}_{2}\right)$ is explained by propane consumption and by all possible reaction paths. Figure 3 also shows that the G-values of formed hydrocarbons (methane, ethane, ethylene and n-butane) are quite constant with increasing dose. These observations are the same for butane, butene and gas mixture radiolysis.

Table 1 compares our measured G-values with other radiolysis studies. There is a large variation of the results. Likely sources of discrepancy are the irradiation conditions and the type of radiation. Another one may be the use of different methods of dosimetric measurements.

\subsection{Pressure effect on hydrogen and hydrocarbon formation}

Propane and butane were irradiated at room temperature at the absorbed dose of $0.6 \mathrm{MGy}$. Irradiations were carried out between 1000 and 480 mbar for propane and 1000 and 350 mbar for butane. Figure 4 shows the dependence of the G-values (for hydrogen and some hydrocarbons formed during propane radiolysis) as a function of the propane pressure. We observe the same effect for all formed products: the G-values are independent of the propane pressure in the range from 1000 to 480 mbar. The same effects are observed for the n-butane radiolysis. 


\subsection{Effect of butene addition on the radiolysis of propane}

In the following experiments, various propane and butene mixtures were irradiated at atmospheric pressure with an absorbed dose of $0.6 \mathrm{MGy}$ and a constant dose rate.

In figure 5, the G-values of hydrogen and some hydrocarbons are shown as a function of the butene percentage in the mixture.

First, concerning hydrogen, $\mathrm{G}\left(\mathrm{H}_{2}\right)$ decreases rapidly from 3.7 molecules per $100 \mathrm{eV}$ for $100 \%$ of propane to a plateau value of 1.1 for $100 \%$ of butene: with $5 \%$ of butene in propane, $\mathrm{G}\left(\mathrm{H}_{2}\right)$ is equal to 2.0; this observation agrees with Miyazaki [4] who found a $\mathrm{G}\left(\mathrm{H}_{2}\right)$ of 2.33 for the radiolysis of nbutane with $5 \%$ of 1 -pentene (see table 1 ).

The G-values of methane and ethane, like hydrogen, decrease rapidly when small amounts of butene are added: in radiolysis of pure propane, $\mathrm{G}\left(\mathrm{CH}_{4}\right)=1.0$ and $\mathrm{G}\left(\mathrm{C}_{2} \mathrm{H}_{6}\right)=1.7$ whereas in pure butene radiolysis, there are equal to 0.26 and 0.29 respectively.

On the other hand, the G-values of ethylene increase with increasing butene addition from 0.5 at $100 \%$ of propane to a plateau value of 1.7 with $100 \%$ of butene.

Butene probably acts as a radical scavenger like ethylene [5] which can intercept radicals $\left(\mathrm{H}^{\bullet}, \mathrm{CH}_{3}{ }^{\bullet}\right.$, ...) formed during radiolysis and prevent formation of molecules like molecular hydrogen, methane, ethane... K. Yang and P. Manno [1] used nitric oxide as a radical scavenger in the $\gamma$-radiolysis of methane, ethane and propane. They found that nitric oxide inhibits the formation of hydrogen and saturated hydrocarbons; moreover, the G-value of formed ethylene increased with increasing nitric oxide concentration. M.D. Scanlon [8] gave the same conclusion with $\gamma$-radiolysis of ethane.

\section{Conclusions and perspectives}

As a conclusion, the extracted beam line is operational at IPN Lyon for irradiation studies, under gas or liquid phase [9]. 
Coupling the irradiation cell to a gas chromatograph allowed us to describe the influence of irradiation parameters on the production of hydrogen and hydrocarbons during propane radiolysis. Those results are preliminary, as identification and quantification of higher hydrocarbons than nbutane are in progress. We also consider irradiating propane with $\alpha$-particles in order to compare radiolytic yields of hydrogen and hydrocarbons to those obtained with protons.

In order to better understand the radiolysis mechanisms in propane, n-butane, butene and mixture of propane and butene, we could study the effect of electron scavengers such as $\mathrm{N}_{2} \mathrm{O}$, radical scavengers like $\mathrm{NO}$ or $\mathrm{O}_{2}$ and ion scavengers such as deuterated hydrocarbons.

\section{Acknowledgment:}

The authors are very grateful to N. Chevarier, N. Moncoffre and N. Toulhouat for very helpful discussions.

\section{References:}

[1] K.Yang, P.J. Manno, J. Am. Chem. Soc. 81 (1959) 3507.

[2] M. Nishikawa, Y. Yamaguchi, K. Fujita, K. Kon, T. Okamota, Can. J. Chem. 51 (1973) 3966.

[3] N. Fujisaki, S. Shida, Y. Hatano, J. Chem. Phys. 52 (1970) 556.

[4] T. Miyazaki, S. Shida, Soc. Jap. 38 (1965) 2114.

[5] Radiation chemistry of hydrocarbons edited by G. Foldiak, Amsterdam, 1981.

[6] R.A. Back, N. Miller, Trans. Faraday Soc. 55 (1959) 911.

[7] J.F. Ziegler, J.P. Biersack, U. Littmark; the Stopping and Range of Ions in Matter; Pergamon press, New York; 1985.

[8] M.D. Scanton, R.J. Hanrahan, Radiat. Phys. Chem. 16 (1980) 201.

[9] S. Lapuerta, N Moncoffre, N. Millard-Pinard, D. Crusset, C. Corbel, E. Mendes, 8th Eur. Conf. on Accelerators in Applied Research and Technology, 2004. 
Figure 1: Scheme of the extracted beam line at IPN Lyon

Figure 2: Spatial distribution of the proton beam for two different pressures: 500 and 1000 mbar of propane

Figure 3: Radiolytic yields of products formed during propane radiolysis as a function of absorbed dose.

Figure 4: Radiolytic yields of products formed during propane radiolysis as a function of pressure.

Figure 5: G-values of hydrogen (figure 5.a) and some hydrocarbons (figure 5.b) as a function of butene percentage in the mixture at $\mathrm{P}=1000$ mbar. 
Figure 1

Extracted beam line

Irradiation cell

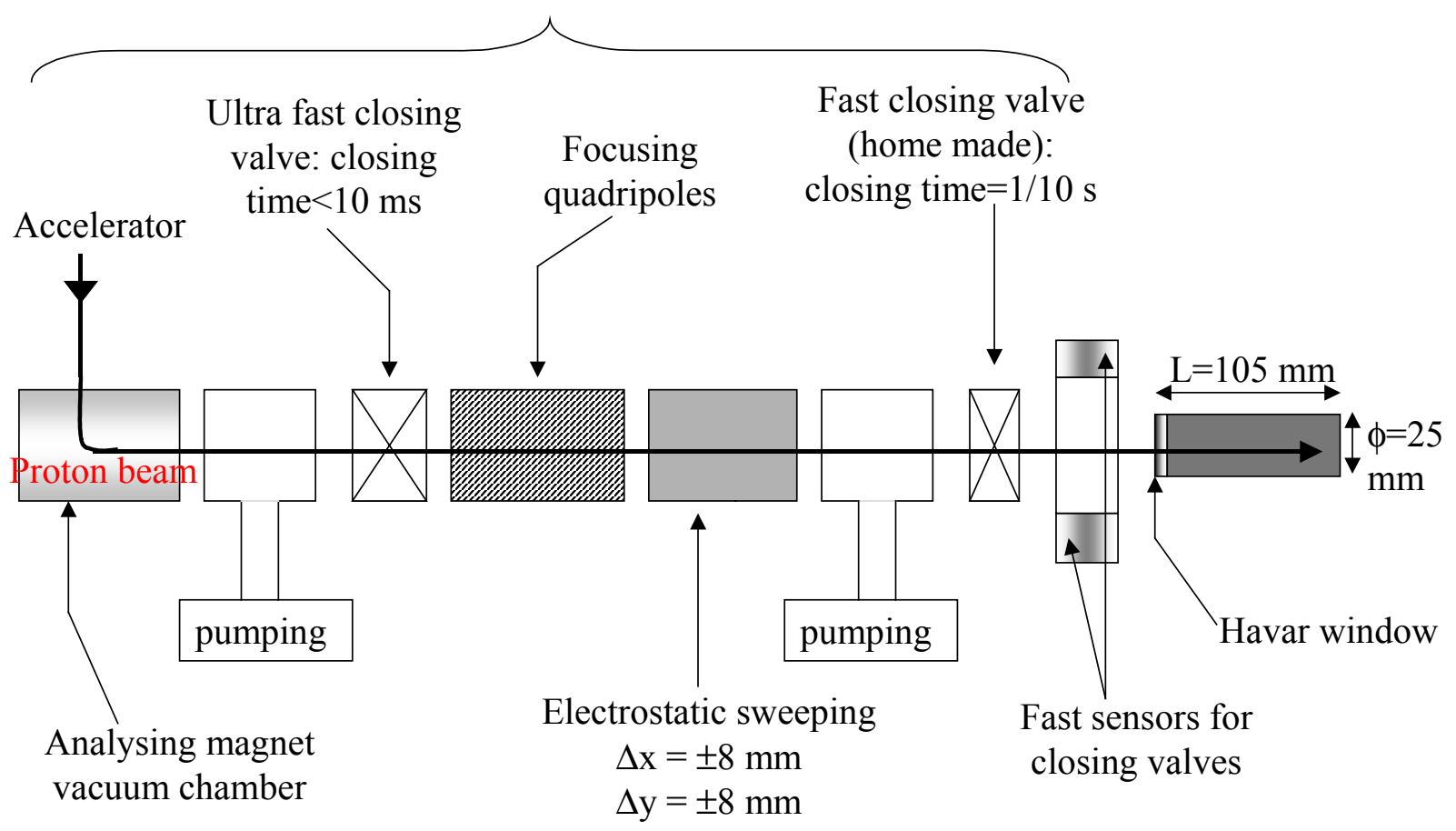

6 meters 
Figure 2:
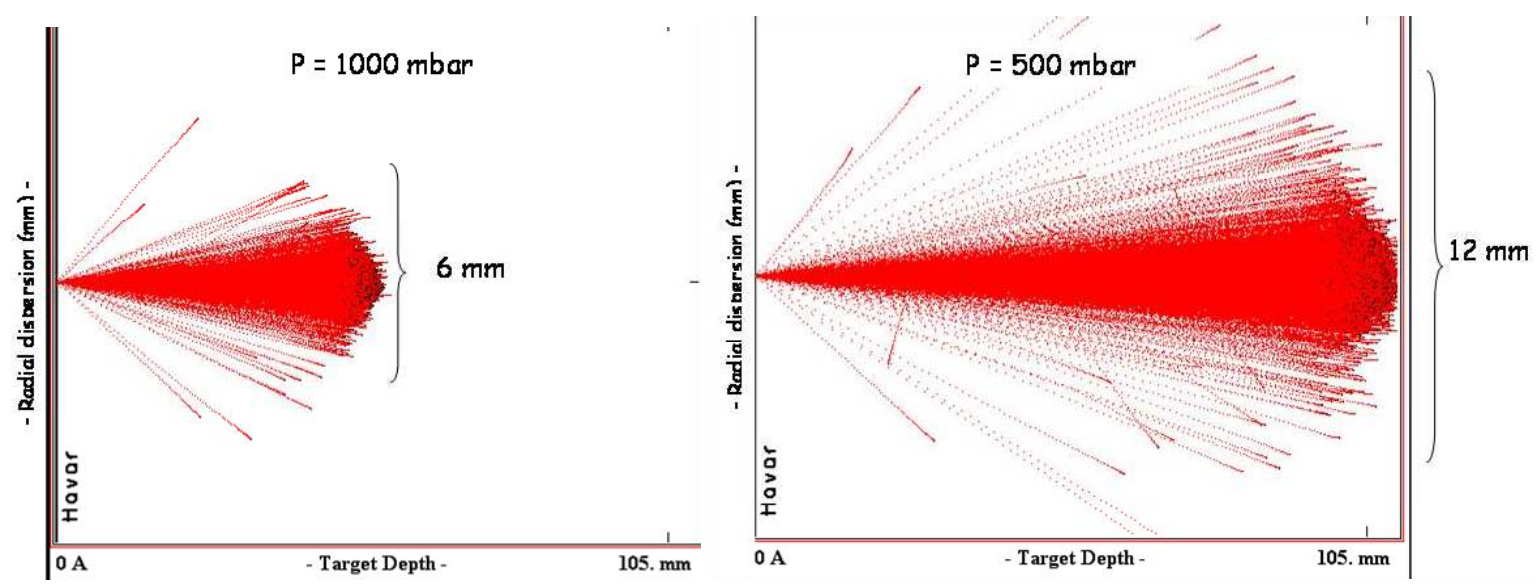
Figure 3:

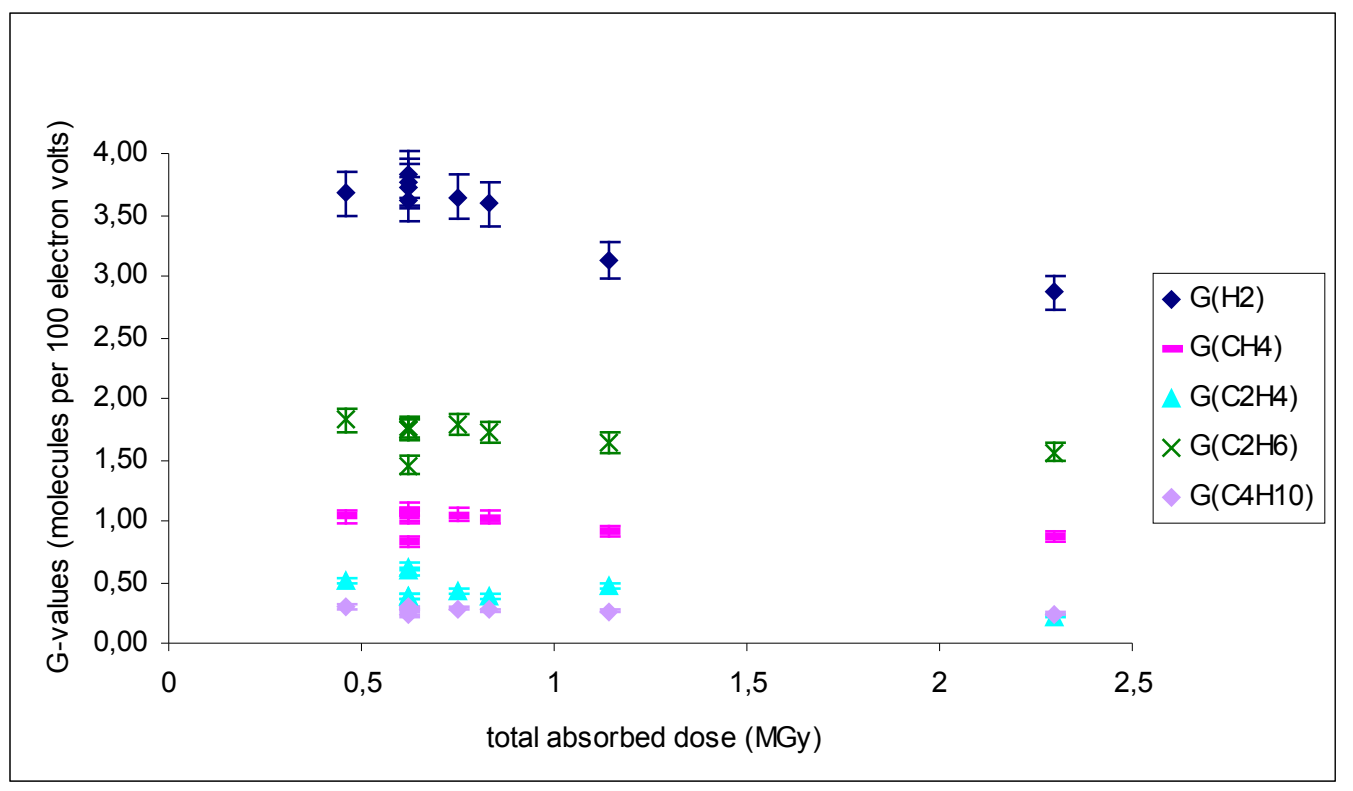


Figure 4:

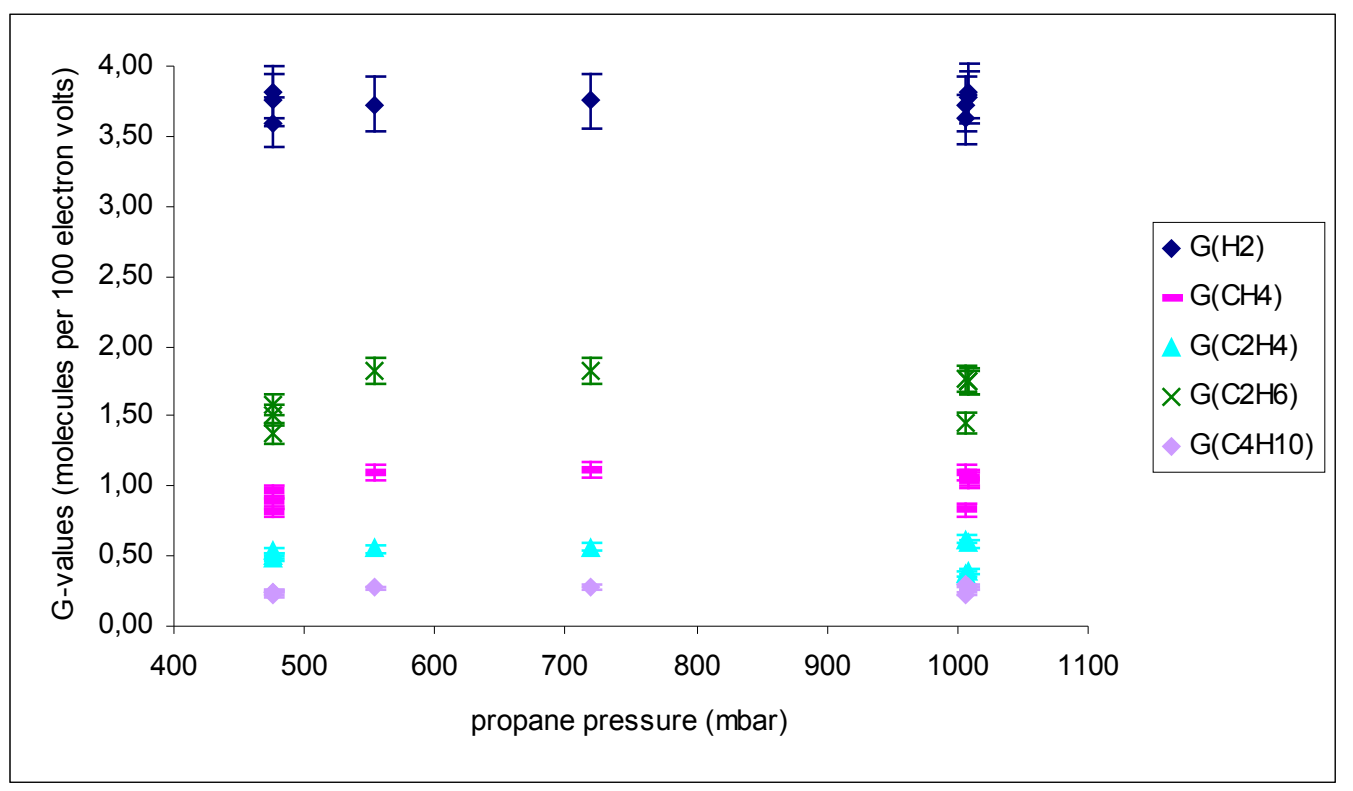


Figure 5:

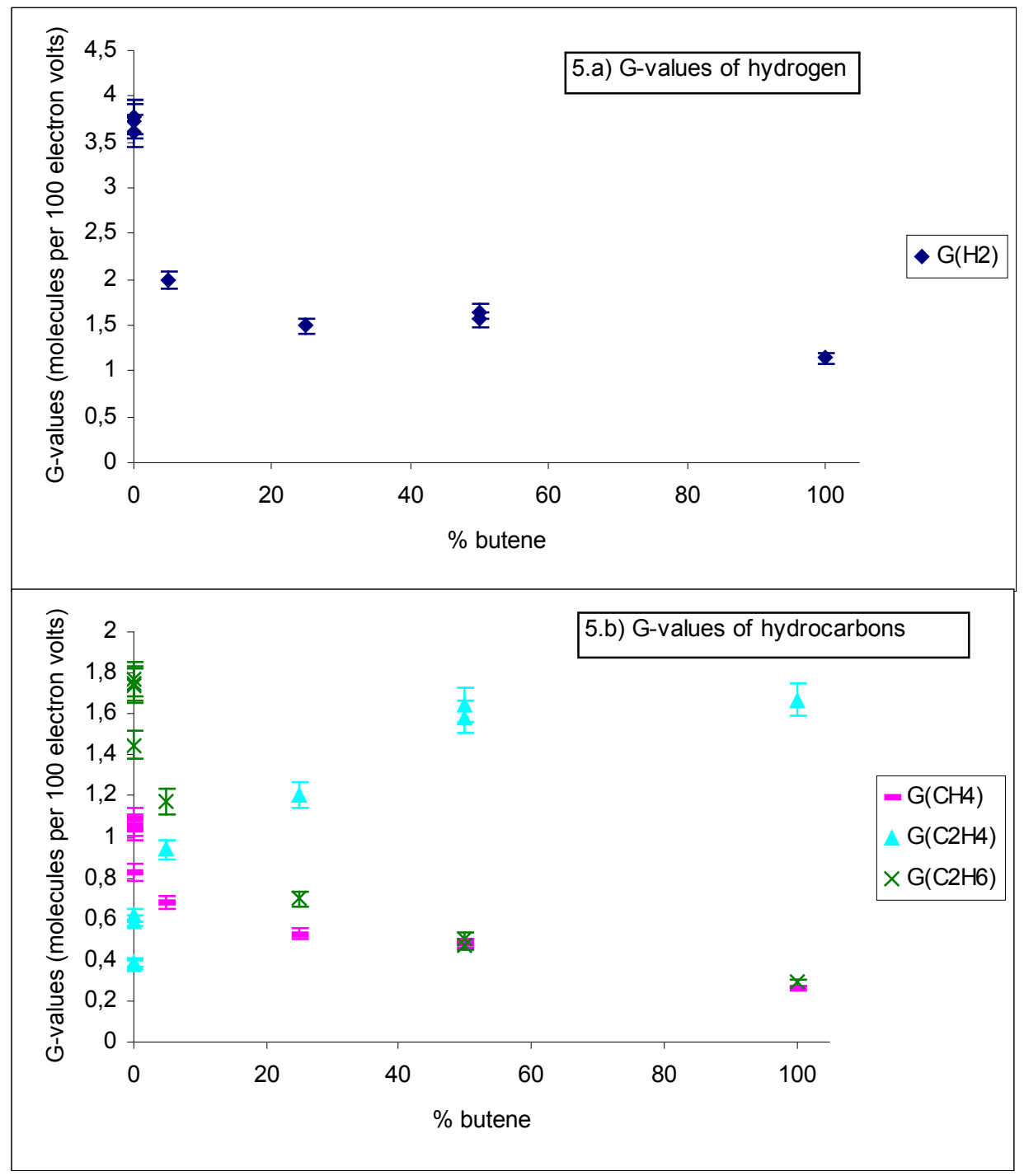




\begin{tabular}{|c|c|c|c|c|c|c|c|c|c|c|}
\hline \multirow[b]{2}{*}{ target } & \multirow[b]{2}{*}{$\begin{array}{l}\mathrm{D} \\
(\mathrm{kGy})\end{array}$} & \multirow[b]{2}{*}{$\begin{array}{l}\mathrm{D}^{\bullet} \\
(\mathrm{kGy} / \mathrm{h})\end{array}$} & \multirow[b]{2}{*}{$\begin{array}{l}\mathrm{P} \\
\text { (mbar) }\end{array}$} & \multirow[b]{2}{*}{$\begin{array}{l}\mathrm{T} \\
\left({ }^{\circ} \mathrm{C}\right)\end{array}$} & \multirow[b]{2}{*}{$\begin{array}{l}\text { Radiation } \\
\text { type }\end{array}$} & \multicolumn{4}{|c|}{ G-values } & \multirow[b]{2}{*}{ ref } \\
\hline & & & & & & $\mathrm{H}_{2}$ & $\mathrm{CH}_{4}$ & $\mathrm{C}_{2} \mathrm{H}_{4}$ & $\mathrm{C}_{2} \mathrm{H}_{6}$ & \\
\hline $\mathrm{C}_{3} \mathrm{H}_{8}$ & 600 & $5610^{3}$ & 1000 & room & $\mathrm{p}$ & 3.7 & 1.0 & 0.5 & 1.7 & $\mathrm{a}$ \\
\hline $\mathrm{C}_{3} \mathrm{H}_{8}$ & - & 3.2 & Atm & room & $\gamma$ & 5.9 & 1.47 & 0.24 & 2.0 & [1] \\
\hline $\mathrm{C}_{3} \mathrm{H}_{8}$ & 1.12 & 0.382 & $6710^{3}$ & 120 & $\gamma$ & 8 & - & - & - & [2] \\
\hline $\mathrm{C}_{3} \mathrm{H}_{8}$ & 10.3 & 10.3 & 2000 & Room & $\gamma$ & 7.4 & - & - & - & [3] \\
\hline $\mathrm{C}_{3} \mathrm{H}_{8}$ & - & 640 & 750 & - & $\alpha$ & 8.2 & 0.37 & \multicolumn{2}{|l|}{$0.54^{b}$} & [6] \\
\hline $\mathrm{C}_{3} \mathrm{H}_{8}$ & - & - & 1000 & 35 & $\gamma$ & - & 1.4 & 1.0 & 2.2 & [5] \\
\hline $\mathrm{n}-\mathrm{C}_{4} \mathrm{H}_{10}$ & 600 & $5410^{3}$ & 1000 & room & $\mathrm{p}$ & 3.4 & 0.4 & 0.6 & 1.1 & $\mathrm{a}$ \\
\hline $\mathrm{n}-\mathrm{C}_{4} \mathrm{H}_{10}$ & - & 640 & 750 & - & $\alpha$ & 9.0 & 1.2 & 1.4 & 1.3 & [6] \\
\hline $\mathrm{n}-\mathrm{C}_{4} \mathrm{H}_{10}$ & 20,6 & 860 & Atm & 150 & $\gamma$ & - & 4.21 & 1.56 & 2.88 & [5] \\
\hline $\begin{array}{l}\text { n- } \\
\mathrm{C}_{4} \mathrm{H}_{10}+\mathrm{C}_{5} \mathrm{H}_{10}\end{array}$ & 400 & 2.3 & 330 & room & $\gamma$ & 2.33 & 1.03 & \multicolumn{2}{|l|}{$2.48^{\mathrm{b}}$} & [4] \\
\hline $\mathrm{C}_{3} \mathrm{H}_{8}+\mathrm{C}_{4} \mathrm{H}_{8}$ & 600 & $4910^{3}$ & 1000 & room & $\mathrm{p}$ & 2.0 & 0.7 & 0.9 & 1.2 & $\mathrm{a}$ \\
\hline
\end{tabular}

Table 1: A comparison of the G-values for the radiolysis products of propane, butane and mixture of hydrocarbons. $\quad \mathrm{a}=$ our results, $\mathrm{b}=\mathrm{G}$-value of $\mathrm{C}_{2} \mathrm{H}_{4}+\mathrm{C}_{2} \mathrm{H}_{6}$ 